\title{
Parental Evaluation of Popular Brand Names Given as Christmas Gifts and Sources of Information Used in These Decisions.
}

\section{Authors}

\section{Peter Clarke}

Is a lecturer at Griffith University in the Department of Marketing. His research interests focus on Christmas consumption, gift giving and consumer behavior. These interests continue from extensive experience in both the toy industry and the Christmas industry. Publications appear in the Journal of Consumer Behavior and Journal of Consumer Marketing and he has delivered papers on consumer behavior at national and international conferences.

\section{Andrew McAuley}

Professor McAuley joined the Department of Marketing as Head of Department in 2009 having previously been Head of Department at the University of Stirling in Scotland. He is the current Chair of the UK Academy of Marketing. His research interests have focused for some time on marketing management issues with the smaller enterprise and their characteristics being of particular interest especially in relation to the marketing/entrepreneurship interface.

\section{Address all Correspondence to:}

Dr. Peter Clarke

Department of Marketing

Griffith Business School

Griffith University, Nathan Campus

170 Kessels Road

NATHAN QLD 4111

Phone: +61 737357352

Fax: $\quad+61737357126$

Email: p.clarke@griffith.edu.au 


\begin{abstract}
Purpose -

Parents' exposure to children's brands appears rather limited; while brands sell at Christmas, there are extraordinary purchases of low-cost toys and stocking filler fun toys. Maybe, toy brand purchases satisfy the child's request, rather than parent's value or quality preferences. Generally, the theories of branding feature the positive functional, symbolic and emotional attributes. The paper examines parental evaluation of popular brand names to be given as gifts at Christmas and the sources used to gather information about brands.
\end{abstract}

\title{
Design/methodology/approach -
}

Data were gathered via a survey of parents in the period prior to Christmas. The analysis consisted of a Principal Component Analysis of the functional, symbolic and emotional evaluations. A frequency analysis and a gender-based crosstabs series identified gender variations in the evaluations and use of information sources.

\section{Findings -}

The study indicated that parents hold low evaluations of popular brands when buying Christmas gifts for their children. These low evaluations are across functional, symbolic and hedonic elements. Since mothers generally attend to the gift purchase decisions, there were significant gender differences on a few evaluations. The most popular source of information is asking children what they want and is closely followed by the use of store catalogues.

\section{Practical implications -}

The evaluation and purchase of toys and gifts predominate at Christmas. Having such a high level of product or brand choice in the children's market could create confusion or uncertainty for parents. A negative image of children's exposure to toy advertising and the resultant Pester Power may combine to cloud parents' evaluations of giving brands as gifts. In essence, Christmas is the major chance for brand owners to sell their toys and other products. The idea of "...ask mom to get one...” may be appropriate in high turnover, supermarket products, but not effective in a one-chance, Christmas gift situation.

\section{Originality/value -}

This research spans the value sets of two generations. Simply, the promotion of toys is primarily directed toward children who develop desires, expectations and values that are different from those values and attitudes of parents. Research into parental Christmas giving ascertains the value of children's brands to parents.

\section{Keywords}

Parents, Brands, Evaluations, Information Sources

\section{Paper type}

Research paper 


\section{Introduction}

The Christmas season is a time of unprecedented gift giving by parents to children and it is also a time of heavy toy advertising. Retailers would spend about $30 \%$ of their annual advertising expenditure across a range of media including television, outdoor and catalogues (Johnson, 2008). However, promotion of brand names and characters are part of the children's television landscape rarely seen by parents or adults. Toys are promoted to children via television, fast food chains (as specialty offers), toy-linked cartoon series, spin-off products from children' programs, and hosted segments within children's' television programs (Young Media Australia, 2004). Ultimately, parents buy toys for children and are the focus of any retailer promotion. The theory and research into the concept of branding extols the positive attributes of branding. While these attributes may suffice in situations concerning particular product categories, there are indications that parental gift giving at Christmas does not adhere to the popular beliefs about branding. This study is important because it addresses parent's evaluation of popular brand names given as gifts and the concomitant use of information sources.

This research commences with Christmas gift giving and parents. The literature provides elements that address parents' use of information sources in the evaluation and selection of gifts. Some gifts may be simple or basic, while others may be known brand names where the functionality, symbolism and emotional aspects of brand theory contribute to the evaluation of popular brand name gifts to children. The method employed arises from a pen and paper survey where the ensuing data were subject to a Principal Component Analysis (PCA), a frequency analysis of all evaluative items and lastly, a series of crosstabs for evaluations and information source usage. An interpretation of the 
results is followed by a discussion of the findings, future research and brief implications arising from this study

\section{Christmas Gift giving}

Gift giving has been a long-standing topic of sociological discourse (Caplow, Bahr, Chadwick, Hill, \& Williamson, 1982; Hirschman \& LaBarbera, 1989). It manifests as a complex psychological and sociological phenomenon of motivations and symbolism that involves a social interaction between givers and receivers. Consequently, gifts are given for social support or rites of passage and the giver acknowledges respect for the recipient through affection, admiration, deference or appreciation (Belk, 1978). Irrespective of the occasion, situation or reason, the choice of a gift denotes a symbolic communication of significant and intangible meanings that reflect, develop and maintain important social relationships or networks (Bell, 1991). Essentially, a gift is a manifestation of functional and social utility that is modified by the emotion of the occasion and conveys a particular message to the recipient. In effect, the gift choice criteria relates to the appropriateness of the gift, and possibly, the brand of the gift object.

In addition to expressing the strength of the relationship and the value of the occasion, the act of gift giving is further described as being either altruistic or agonistic. Altruistic gift giving is selfless in seeking and maximizing pleasure for the recipient (Beatty, Man-Hee, Grunert, \& Helgeson, 1996; Goodwin, Smith, \& Spiggle, 1990). Agonistic gift giving represent the self-interest of givers who seek some type of strategic or personal gain together with the rewards associated with giving and derive the maximum pleasure for the giver (Goodwin et al., 1990; Sherry, McGrath, \& Levy, 1993; Wolfinbarger, 1990). 
Generally, the joy and pleasure of giving reflects the spirit of the giver because a part of the giver accrues to the gift and, the gift is often a social statement rather than a contribution to the recipient's material well being (Schudson, 1986). However, giving to children at Christmas respects the spirit of the receiver (Belk, 1987; Caplow et al., 1982). While there are religious and community values associated with the occasion, Christmas is described as an adult-centric, emotional, hedonic and symbolic consumption occasion that facilitates gift giving by parents to their children (Clark, 1995 p.30).

\section{Adults’ Gift Giving Behavior and Information Sources}

Gift giving selection and purchase is a form of choice or decision behavior where the search for the right gift is a part of the Christmas ritual. Females are the principal instigators of gift giving practices and activities within a family context (Hill \& Romm, 1996; Laroche, Saad, Cleveland, \& Browne, 2000). As such, women invest more time, energy and thought than any other family members in all aspects of the gift giving process (Cheal, 1987; Fischer \& Arnold, 1990), and are more involved than men in Christmas shopping and gift giving. Ultimately, women have intimate knowledge of children's likes and dislikes through traditional nurture and care activities with their children.

As in most purchases, adults incur search and shopping behaviours that include price or component comparisons, in-store promotions and advertised specials in newspapers and store flyers (Putrevu \& Lord, 1999). Kiel and Layton (1981) refer to a trio of information source groups, which are retail (store visits), neutral (catalogues or magazines), and personal sources (word of mouth). As such, these avenues are influenced by evaluative feelings and either a positive or a negative views of product or brands (Wilson \& 
Peterson, 1989). Shoppers locate along an organized / unorganized continuum of selection and purchase of gifts that integrates with a negative / positive attitude toward the commercial campaigns of Christmas (Guru \& Tinson, 2003).

On the other hand, children seem information dominant in the areas of toys, clothing, audio-visual, books and sports paraphernalia (Meegan, 1993). McNeal (1992) cites television, store shelves, catalogues and peers as being important for children's information sources. However, product placement in movies, as well as the featured anime and cartoon characters themselves, appears primarily aimed at children and adults as a secondary audience. As a rule, younger children co-viewed television programs more often with parents than did older children and such co-viewing declines from the age of three to seven across most program categories (St. Peters, Fitch, Huston, Wright, \& Eakins, 1991). Consequentially, parents’ minimal exposure to children’s toy commercials suggests limited direct product knowledge.

For adults, television builds an emotional bond with the brand; however, print media is the appropriate method that provides rational reasons for buying a brand. The majority of content found in toy catalogues satisfies informational motives that are ultimately parent orientated because parents buy the gifts that are given at Christmas by Santa Claus. A catalogue lets parents know what is available, what is the price, an illustration as a prompt and a brief description that allows most of the decision process to be conducted at home (Stell \& Paden, 1999). In the context of Christmas giving, parents manage the problems of Christmas gift selection and purchases that include what to buy, the appropriateness of the gift, how much should be spent and where to make the purchase. 
Those that plan for Christmas celebrations appear to respond to television advertising, printed material and in-store advertising (Guru \& Tinson, 2003).

To make sure the gift is the one desired, children use catalogues to source cut-outs and images to convey or qualify their requests for gifts (O'Cass \& Clarke, 2002). Letters written to Santa are a source of information about brand preferences. Observations by Clarke (2008) indicate that, when parents write or co-write letters to Santa, they appear to disfavor or are disinclined to identify gifts in terms of popular brand names.

\section{Brand Theory}

The marketing literature generally refers to a brand as a unique name, term, sign, symbol or design that differentiates products and represents a strong feature in making decision choices. Consequently, a consumer's perception of a brand is meant to engender both rational and emotional confidence where trust and faith in the brand strengthens through time and experience (de Chernatony \& Riley, 1998). Therefore, advertising a brand name explicitly conveys a product benefit that is consistent in meaning with the brand name (Ruth, 2001) to the extent that consumers rely on this sign of quality, and their accumulated brand knowledge for purchase decisions (DelVecchio, 2001). Since advertising promotes favorable brand attitudes and brand selection, any purchase decisions typically involve a selection among different brands of a given product category (Kokkinaki \& Lunt, 1999; Phelps \& Hoy, 1996). Generally, consumers use advertising as a guide to the status of various goods and determine that these goods would be suitable for, and acceptable, as gifts (Schudson, 1986). Previous input to brand consumption theory covers awareness (Percy \& Rossiter, 1992), attribute measures (Mantel \& Kardes, 1999), brand equity (Cobb-Walgren, Ruble, \& Donthu, 1995), brand 
personality (Aaker, 1997) or combinations of experiential, hedonic, symbolic and functional brand consumption relationships (Babin, Darden, \& Griffin, 1994; Hopkinson \& Pujari, 1999; Mano \& Oliver, 1993).

Brand benefit associations are applicable to describing specific brands or the comparison of nominated brands in a product category. Since brand benefit associations apply to one or many brands, logic suggests that these associations also apply to bundles of brands. Bundling or grouping of brands is evident in the literature. One study, by DelVecchio, (2001), described 'private labels' as a group or bundle of brands rather than specific private brands. An earlier study by Moschis (1981) offered a scale that measured attitudes toward non-specific, branded products and, as a collective concept, private labels exhibit characteristics of social symbols and quality cues (Burton, Lichtenstein, Netemeyer, \& Garretson, 1998).

Many brand names in the toy and games industry follow a fad-style life cycle and never reach a status of being popular. However, the industry abounds with popular brand names; some stand the test of time and some brands are revived and updated every few years. In general, brands can be popular for a long time, a short time or not at all. Some sections of the literature refer to non-specific group of brands such as children's brands (McNeal, 1992) and some people class other categories of brands as, for instance, foreign brands, national brands or industrial brands. Overall, bundles or groups of brands can be described in generic terms because brand benefit associations apply to one or many brands (Keller, 1993).

The evaluation of brand names is an area of strong research interest. One study concerned similarity of product features and brand concept consistency (Park, Milberg, \& 
Lawson, 1991) while another outlined adult and children's evaluation of brand extensions using various product features interpreted within a brand evaluation context (Zhang \& Sood, 2002). A different path presented by Keller (1998) involves a brand knowledge schema based on the primary components of brand awareness and brand image. Brand awareness relates to brand recall and brand recognition; brand image refers to brand associations and the strength, uniqueness and favorability of those associations. A consumer's perception of the brand derives from attribute, attitudinal or benefits associations (Keller, 1998; Percy \& Rossiter, 1992). Keller (1993) describes brand attitude as "the personal value customer's attach to the product or service attributes - that is, what consumers think the product or service can do for them" and is conceptualized in his brand knowledge schema as a brand association. Although specific brands have specific qualities, this schema suggests a range of generic brand characteristics have applications to any or all brands and is useful to identify and focus on smaller components of brand research.

Past research into brand benefits covers a number of topics and forms the basis for measurable scales relating to functional, hedonic and symbolic attributes of brands. A number of studies highlight utilitarian and hedonic features (Babin et al., 1994; Batra \& Aholta, 1991; Spangenberg, Voss, \& Crowley, 1997). Other studies simply concentrate on hedonic consumption (Hirschman \& Holbrook, 1982; Hopkinson \& Pujari, 1999; Mano \& Oliver, 1993). Ultimately, highly brand conscious consumers find relatively prestigious name brands highly desirable (Sproles, 1974). Thus, brand conscious consumers rely highly on brand prestige when making decisions and follow a path from 
brand consciousness to hedonic value that is significant and positive (Babin, Gonzalez, \& Christina, 2007).

\section{Brand Attributes}

When Bhat and Reddy (1998) refer to functionality, they view the brand as being practical and the user as also being practical or down to earth. However, other considerations of functional or useful characteristics of brands would incorporate a range of positive elements that include practicality, as well as necessity, effectiveness and efficiency (Batra \& Aholta, 1991; Spangenberg et al., 1997). These functional-style elements are important to people when purchasing toys as gifts because (Dussart, 1989) cites poor quality, expensiveness and unreliable warranties as causing parents’ disappointment with giving presents to their children. Hence, if products that become gifts have utility (Sherry, 1983), quality (DeVere, Scott, \& Shulby, 1983; Wagner, Ettenson, \& Verrier, 1990) and an accessible guarantee (DeVere et al., 1983), then giving brand names as gifts means there is a guaranteed value, quality and intrinsic utility that is expected or sought. In effect brand utility or functionality lowers the risk of giving a poor gift.

While altruistic giving associates with the receiver, agonistic giving provides the majority of pleasure to the giver (Goodwin et al., 1990). Ultimately, gift giving to children is a rich mix of pleasure for the child and pleasure for the parents. The essence of hedonic terms means that major positive indicators are pleasure, fun and excitement, while subsequent, yet equally strong terms, cover happy, delightful, cheerful or thrilling (Batra \& Aholta, 1991; Spangenberg et al., 1997). If it is a pleasure or a joy to give a gift to children at Christmas, then rewards arise from the gift being positive and well-received. 
If pleasure is a hedonic component that aligns with other brand characteristics, then equivalent hedonic elements are also functions of brand characteristics.

Symbolic characteristics can be orientated to either the brand name or the user; these are distinct forms of symbolism (Bhat \& Reddy, 1998). Brand names encompass social approval, personal expression and self-concept that create the symbolic benefits, such as the socially visible badges that accrue to product or service use (Keller, 1998). Symbolic consumption is also orientated toward the user, and within the context of this study, the giver is the user. Therefore, giving brands as gifts at Christmas means such themes as looking good, being noticed and sign value are present and accrues to the giver; along with functional utility and hedonic elements.

Allen \& Ng (1999) argue that symbolic attributes are associated with functionality and Bhat \& Reddy (1998) indicate that the brand image of symbolic and functional characteristics facilitate the positioning of a brand in relation to other brands. The focus of Bhat and Reddy (1998) is on the positioning attributes of specific brands for functionality and the bi-dimensional brand symbolism of prestige and personality expression. Generally, these elements are a combination of brand and user; not those items that exclusively attach to a brand or singularly attach to the giver. Other brandrelative items suggest that, if a gift that is well received, it has status or prestige; since a brand may be the best gift to give, it also holds a theme of distinctiveness. If a brand is practical, it exhibits utility or functional elements of quality and a guarantee that co-exist with those hedonic, prestigious and distinctive elements.

The study takes an initial step toward explaining parent's gift giving at Christmas and is part of a larger Christmas gift giving inquiry that sought responses from a sample of 
parents with children between the ages of 3 and 8 years. Clark (1995) argues that Santa Claus and Christmas is a fantasy, make-believe occasion for children that is encouraged by adults, and in her book, many quoted comments and responses are from children around 6 to 7 years old. Similar age distributions feature in Richardson \& Simpson (1982), Carlson, Grossbart, \& Walsh (1990) and Rose, Bush, \& Kahle (1998).

Consequently, designation of the sample frame as a parent with at least one child between the ages of 3 to 8 years is appropriate. Apart from the specified age group, families will have children that are older and younger than the age range, and thus, as Rook (1985) observes, families will have the experience to personalize the Christmas celebration script and gift giving traditions.

In particular, the purpose of this study is to gain an understanding of parent's evaluation of popular names when considered as gifts for Christmas. The method entails the development of a pen and paper survey questionnaire, delivered to participating schools and kindergartens, for children to take home to their parents.

\section{Method}

Past studies concerning brand benefit associations generally describe specific brands or compare nominated brands in a product category. The development of the brand benefit items required adaptation and aggregation of functional, hedonic and symbolic items modified from the literature. Item statements reflect a combination of elements from the brand benefits advocated by (Keller, 1993; 1998), the positioning of brands outlined by Bhat \& Reddy (1998) and the social utility aspects of consumption Sheth, Newman, \& Gross (1991). The final elements encompassed utility benefits of brand quality or guarantees, hedonic elements of joy, pleasure, being well received and symbolic 
elements, such as signs of success or identity. In addition, items and ideas from Babin et al. (1994); Batra \& Aholta (1991); Bhat \& Reddy (1998); Hirschman \& Holbrook (1982; Hopkinson \& Pujari (1999); Mano \& Oliver (1993); and Spangenberg et al. (1997) contributed to the 16 items employed in this study. These brand focus statement employed a 7-point likert-style, scale format from 1 (strongly disagree) and 7 (strongly agree) as well as nominal responses for gender identification and income spread.

Development of the final survey instrument relied on the input of an expert panel, a group of mothers from a day care centre, a pilot study and the final survey of parents. The timing of this study corresponded with the arrival of Santa at the shopping centers around the first week of November. Together with store decorations and seasonal advertisements, a six-week shopping event suggests parents appear to be most concerned about fulfilling Christmas celebrations and making gift purchases for their children. The questionnaire package contained a letter of introduction and return instructions, a survey instrument for both parents and a pre-paid, pre-addressed return envelope. The schools organized the distribution of the packages to parents during the month of November and completed questionnaires were received over the intervening weeks up to a cut off date of the 20th of December. Overall, 2560 individual surveys were distributed and 463 returned of which 450 individual cases were suitable for analysis. Return rates varied by the institution and ranged from $2 \%$ to $35.6 \%$ for an overall effective return rate of $17.6 \%$.

\section{Results}

There were 271 female and 179 male respondents. Weekly household incomes ranged from a minimum of $\$ 160$ up to $\$ 3000$ + per week where 30\% of the sample had a combined income up to $\$ 1000$ per week, 55\% reported an income between $\$ 1000$ and 
$\$ 2000$, and $15 \%$ earned in excess of $\$ 2000$ per week. The dominant family structure was male, female parents and two children (Average age of 5 years, 6 months). The sample provided a broad range of parental age, incomes and age of children that cover different levels of experience in giving to children at Christmas.

The data responses were to set questions within three distinct groupings of utility, hedonic and symbolic evaluations that followed the views of Keller (1993) and Bhat \& Reddy (1998). The analysis concentrated on three statistical procedures. The first step required a simple data reduction process based on the obtained responses for the evaluations through the use of a Principal Component Analysis (PCA). The second step involved a frequency analysis of all evaluative items and lastly, a series of crosstabs based on the gender of the parents. The use of information sources was also subject to a frequency analysis and a gender-based crosstabs series.

As displayed in Table 1, the utility factor explained $75.2 \%$ of the variance, featured three strong loadings above .842 and a reliability of .83. The five hedonic items explained $57.0 \%$ of the variance, featured strong loadings above .722 and a reliability of .80 . However, the symbolic measures that relates to the sign, image or badge value revealed a two factor structure from the eight symbolic evaluations of giving PBN as gifts. An initial PCA delineated two factors where the items, giving the hottest brand (Mean 1.24, StdDev 0.75) and giving brands just to be noticed (Mean 1.63, StdDev 1.11) formed a second factor. These two items loaded approximately equal across the two factors and subsequently deleted. Thus, the final symbolic factor of six items explained 53.2\% variance, displayed loadings above .686 with a reliability of .81 . 
The results necessitated exploration of possible reasons for the deletion of the two symbolic items. A frequency analysis of these items revealed that the giving brands just to be noticed statement drew $97.1 \%$ disagreement, $1.1 \%$ undecided and $2.8 \%$ in agreement with the statement. Responses to Giving the hottest brand statement were 92.2\% disagreement, 2.7 undecided and 5.1\% in agreement. Finding that both statements attracted low means and narrow Std.Dev predicated a frequency analysis of each item.

The measurement statements (Table 2) revealed all item responses favoured disagreement with means being under 2.92 within a 1 - 7 response spread. Disagreement levels ranged from $61.2 \%$ to $97.1 \%$; undecided level responses ranged from $1.1 \%$ to $10.8 \%$ and agree levels went from a low $2.8 \%$ to a high of $28 \%$.

Take in Table 2

There were no statistical differences between mothers and fathers evaluations of brands as gifts except in the one instance where mothers predominate in the thought that giving a good Christmas gift meant giving a popular brand name as a gift (Chi Square10.80, df 5, $\mathrm{p}<.05)$.

Parents not only seek information about desires, wishes and gift preferences; they also seek information on brand names and availability. Consequently, parental gender and use of information sources were explored through a series of crosstabs (Table 3). Significant differences arose with the use of press advertisements (Chi Square28.01, df 6, p=.000), catalogues (Chi Square28.01, df 6, p=.000) and toy departments (Chi Square21.08, df 6, $\mathrm{p}=.002$ ). Personal sources showed significant differences when asking my children (Chi Square15.85, df 6, p=.015) and asking other children (Chi Square19.41, df 6, p=.003). In all cases mothers predominated in the use of these information sources. 


\section{Discussion}

At a broad level, surprise, suspense, sacrifice and sharing represents the essential elements of parental Christmas giving. While these elements seem intuitive, gift purchasing incorporates evaluations of the gift prior to purchase. Essentially, these evaluations are through functional, symbolic or emotional elements at both product and brand selection tasks. Whilst some aspects of marketing research categorizes adult gift exchange attitudes, motivations or strategies (Laroche, et al 2000), the issue of brandname evaluations is a valuable, contributing topic of research.

Each factor delineated in this study has acceptable structure and reliability. Overall, the low ratings suggest that parents are least concerned about giving popular brand names which is contrary to the view of Hill \& Romm (1996)who suggest that parents give brands as best quality gifts. However, the three utility items hold the highest agree response percentage and there appears a belief that PBN gifts ease the chances of given a poor gift. The utility factor appears to qualify the various perceptions of participants within a gift exchange that giving a useful or practical gift is the ultimate criteria.

This finding of low benefits from giving popular brand names as gifts is consistent with some sections of the popular press. As a rule, major retailers appear to promote themselves as brand-oriented companies that aim to build customers' trust by offering quality well-known brands at everyday low prices. People ask for specific toys by name; these toys are the most heavily advertised and discounted at retail level because they attract shoppers. Many toy offerings include larger ranges of private label toys that are lower-cost versions of heavily advertised brand-name toys. El Boghdady (2003) reports 
a mother's reaction to advertised brands implied that a 2 and 1/2-year-old girl couldn't tell the difference between Barbie and any other fashion doll, while her 9-year-old was not brand selective. This mother felt that "as long as the kids like a toy and it keeps them busy, the brand doesn't matter at all". On the other hand, older children generally nominate a specific brand they want to have and that is what parents want to buy. Every year, some toys stand out among the thousands and media reports of their scarcity drive sales (De Silva, 2003). Brand owners also extol the success of their promoted items and press articles report massive demand for specific toys and games during Christmas. The general opinion is that people buy popular toy brands at Christmas because such brands do become scarce; they are often used as lost leaders and people perceive value in a discounted brand. Others may see price-cutting as reducing the trust and value of a brand (Zimmerman, Pereira, \& Kim, 2003). Because children's products and brands have a faddish life cycle, parents may view brands as not only dubious quality but also expensive and, therefore, giving brands as gifts may be lowly rated. This reinforces (Dussart, 1989) view that parents' disappointment with giving presents to their children occurs because of poor quality, expensiveness and unreliable warranties. As Sharpe (2003) indicates, there are simply too many toys to choose from, the prices of some brand name toys appear unreasonable and alternate choices come from educational toys and just for fun items.

Whilst parents evaluate PBN gifts lowly, they still purchase PBN and thus would do so for different reasons. Alternatively, people want choice; they seek boutique products (De Silva, 2003) and may not be willing to pay the price of advertised brand names. Consequently, the low evaluation of popular brand names may reflect the changes from 
the highly influential brands that were featured on children's TV in the 1980’s (Pecora, 1998), to one of choice that coincides with the different parental values. Global brand dominance in the toy industry is acknowledged but questionable when there is a plethora of non-promoted, well priced and acceptable toys available. A simplistic view sees toys simply as a doll, a soft toy, a bike, a truck, car, boat or plane and most toys, advertised or not, fall into these categories. Electronic based toys and games are just variations, as are most advertised brands which still sell and are the focus of departmental stores buying and promotional practices.

\section{Future Research}

One important outcome of the current study is the extension to contemporary knowledge about giving brands as gifts. Academic and industry literature refers to general categories of brands such as industrial brands, household brands or children’s brands. These measures of the evaluations of giving brands as gifts extends brand theory to include a popular brand name category rather than relying on individual brand comparisons to extend theory. The items comprising the brand evaluation measures in this study should prove adaptable to other groups of brands or individual brands alike and could form the basis for assessing brand evaluations and preferences within a given set of brands.

Research into gift giving practices places an emphasis on the grouping givers' attitudes into behavioral groups and the next research topic relates to such groups and their evaluation of brand names considered as gifts.

\section{Conclusion}


Christmas and gift giving research continues to mature and develop both theoretically and empirically. Understanding the benefit evaluations of giving popular brand names as gifts is a significant aspect of this research because parents buy both major and minor brands to give as gifts to their children. This study is important and takes a significant step toward developing brand theory relating to Christmas and parental gift giving.

\section{Implications for Business}

The results and conclusions drawn from this study indicate that the low evaluation of benefits accruing to popular brand names may represent an overall failure of brand owners, and advertisers, to appeal to parents directly, rather than using children as an element of their promotional package. Therefore, promotions with specific messages for adults may help to overcome misinformation, low evaluations and the dislike or aversion to giving popular brand names as gifts. The continuing and increasing use of product licensing means growth through brand extensions. As children's brands leave the exclusive domain of the children's market and move into the adult orientated markets it means that adults may not recognise, approve of or trust the brand. On the other hand, the continuous expansion of the children's market through the introduction of non-toy or adult brands into the children's segment infers that parents already have the appropriate knowledge and preferences. 


\section{References}

Aaker, J. L. (1997). Dimensions of brand personality. Journal of Marketing Research, 34 (3), 347-356.

Allen, M. W., \& Ng, S. H. (1999). The direct and indirect influences of human values on product ownership. Journal of Economic Psychology, 20 (1), 5-39.

Babin, B. J., Darden, W. R., \& Griffin, M. (1994). Work and/or fun: Measuring hedonic and utilitarian shopping value. Journal of Consumer Research, Vol. 20 (4) (March), 644-656.

Babin, B. J., Gonzalez, C., \& Christina, W. (2007). Does santa have a great job? Gift shopping value and satisfaction. Psychology and Marketing, Volume 24 ( Issue 10), 895 - 917.

Batra, R., \& Aholta, O. (1991). Measuring the hedonic and utilitarian sources of consumer attitudes. Marketing Letters, Vol 2 (Iss 2), 159-170.

Beatty, S. E., Man-Hee, Y., Grunert, S. C., \& Helgeson, J. G. (1996). An examination of gift giving behaviors and personal values in four countries. In C. Otnes \& R. F. Beltramini (Eds.), Gift Giving: A Research Anthology (pp. 19-36). Ohio: Bowling Green State University Popular Press.

Belk, R. W. (1978). Gift-Giving Behavior. In J. N. Sheth (Ed.), Research in Marketing (Vol. 2, pp. 95 - 126). Greenwich, Conn.: Jai Press.

Belk, R. W. (1987). A Child's Christmas in America: Santa Claus as Diety, Consumption as Religion. Journal of American Culture, 10 (1 Spring), 87-100.

Bell, D. (1991). Modes of exchange: Gift and commodity. Journal of Socio-Economics, Vol 20 Summer (2), 156-168.

Bhat, S., \& Reddy, S. (1998). Symbolic and functional positioning of brands. Journal of Consumer Marketing, 15 (1), 32-44.

Burton, S., Lichtenstein, D. R., Netemeyer, R. G., \& Garretson, J. A. (1998). A scale for measuring attitude toward private label products and an examination of its psychological and behavioral correlates. Journal of the Academy of Marketing Science, 26 (4), 293-306.

Caplow, T., Bahr, H. M., Chadwick, B. A., Hill, R., \& Williamson, M. H. (1982). Middletown Families: Fifty Years of Change: Minnesota Press.

Carlson, L., Grossbart, S., \& Walsh, A. (1990). Mothers' communication orientation and consumer-socialization tendencies. Journal of Advertising, 19 (3), 27-38.

Cheal, D. (1987). 'Showing them that you love them': Gift giving and the dialetic of intimacy. Sociological Review, 35 (1), 151-169.

Clark, C. D. (1995). Flights of Fancy, Leaps of Faith: Children's Myths in Contemporary America. Chicago: The University of Chicago Press.

Clarke, P. (2008). Parental communication patterns and children's Christmas requests. Journal of Consumer Marketing, 25 (6), 350-360. 
Cobb-Walgren, C. J., Ruble, C. A., \& Donthu, N. (1995). Brand equity, brand preference, and purchase intent. Journal of Advertising, 24 (3), 25-40.

de Chernatony, L., \& Riley, F. D. O. (1998). Modelling the components of the brand. European Journal of Marketing, Vol 32 (No 11/12), 1074-1090.

De Silva, J. (2003, 17 December). Kids 'R' Us. The Age.

DelVecchio, D. (2001). Consumer perceptions of private label quality: The role of product category characteristics and consumer use of heuristics. Journal of Retailing and Consumer Services, Volume 8 (September, Issue 5), 239-249.

DeVere, S. P., Scott, C. D., \& Shulby, W. L. (1983). Consumer perceptions of gift-giving occasions: Attribute saliency and structure. In R. Bagozzi \& A. Tybout (Eds.), Advances in Consumer Research (Vol. 10, pp. p185-190). Provo UT: Association for Consumer Research.

Dussart, C. (1989). Pre-Christmas toy guides: A cross sectional research study. In T. Srull (Ed.), Advances in Consumer Research (Vol. 16, pp. p 374-383). Provo UT: Association for Consumer Research.

El Boghdady, D. (2003). Knockoffs for the Toy Box? Retrieved 3 March 2004, 2004

Fischer, E., \& Arnold, S. J. (1990). More than a labor of love: Gender roles and Christmas gift shopping. Journal of Consumer Research, Vol. 17 (3) (December), 333-345.

Goodwin, C., Smith, K. L., \& Spiggle, S. (1990). Gift-giving: Consumer motivation and the gift purchase. In M. Goldberg, G. Gorn \& R. Pollay (Eds.), Advances in Consumer Research (Vol. 17, pp. 690-698). Provo, UT: Association for Consumer Research.

Guru, C., \& Tinson, J. (2003). Early evangelist or reluctant Rudolph? attitudes towards the Christmas commercial campaign. Journal of Consumer Behaviour, 3 (1), 48 62.

Hill, C. F., \& Romm, C. T. (1996). The role of mothers as gift givers: A comparison across three cultures. In K. Corfman \& J. Lynch (Eds.), Advances in Consumer Research (Vol. 23, pp. 21-29). Provo UT: Association for Consumer Research.

Hirschman, E. C., \& Holbrook, M. B. (1982). Hedonic consumption: Emerging concepts and propositions. Journal of Marketing, 46 (Summer), 92-101.

Hirschman, E. C., \& LaBarbera, P. A. (1989). The meaning of Christmas. In E. Hirschman (Ed.), Interpretive Consumer Research (pp. 136-147). Provo UT: Association for Consumer Research.

Hopkinson, G. C., \& Pujari, D. (1999). A factor analytic study of the sources of meaning in hedonic consumption. European Journal of Marketing, Vol 33 (No 3/4), 273290.

Johnson, C. (2008, 19 August 2008). Xmas comes early in toyland. Retrieved 14 November, 2009, from http://www.bandt.com.au/news/5b/0c05865b.asp 
Keller, K. L. (1993). Conceptualizing, measuring, and managing customer-based brand equity. Journal of Marketing, 57 (1), 1-22.

Keller, K. L. (1998). Strategic Brand Management : Building, Measuring and Managing Brand Equity. Upper Saddle River, N.J.: Prentice Hall.

Kokkinaki, F., \& Lunt, P. (1999). The effect of advertising message involvement on brand attitude accessibility. Journal of Economic Psychology, 20 (1), 41-51.

Mano, H., \& Oliver, R. L. (1993). Assessing the dimensionality and structure of the consumption experience: Evaluation, feeling, and satisfaction. Journal of Consumer Research, Vol. 20 (3) (December), 451-466.

Laroche, M., Saad, G., Cleveland, M., \& Browne, E. (2000). Gender differences in information search strategies for a Christmas gift. Journal of Consumer Marketing, 17(6), 500-522.

Mantel, S. P., \& Kardes, F. R. (1999). The role of direction of comparison, attributebased processing, and attitude-based processing in consumer preference. Journal of Consumer Research, Vol. 25 (4) (March), 335-352.

McNeal, J. U. (1992). Kids as Customers : A Handbook of Marketing to Children. New York: Lexington Books.

Meegan, G. (1993). News update: World for Kids targets service. The Toy and Hobby Retailer, 6 July, 5.

Moschis, G. P. (1981). Patterns of consumer learning. Journal of the Academy of Marketing Science, Spring Vol. 9 (No. 2), 110-126.

O'Cass, A., \& Clarke, P. (2002). Dear Santa, do you have my brand? A study of the brand requests, awareness and request styles at Christmas time. Journal of Consumer Behaviour, September Vol.2 (no. 1), 37-53.

Park, C. W., Milberg, S., \& Lawson, R. (1991). Evaluation of Brand Extensions: The Role of Product Feature Similarity and Brand Concept Consistency. The Journal of Consumer Research, Vol. 18 (No. 2 (Sep., )), pp. 185-193.

Pecora, N. O. (1998). The Business of Children's Entertainment. New York: Guilford.

Percy, L., \& Rossiter, J. R. (1992). A model of brand awareness and brand attitude advertising strategies. Psychology and Marketing, 9 (4), 263-274.

Phelps, J. E., \& Hoy, M. G. (1996). The Aad-Ab-PI relationship in children: The impact of brand familiarity and measurement timing. Psychology and Marketing, 13 (1) (January), 77-105.

Putrevu, S., \& Lord, K. R. (1999). Consumer grocery search: Dimensions and segments. In European Advances in Consumer Research (Vol. 4, pp. 112-118). Provo UT: Association for Consumer Research.

Richardson, J. G., \& Simpson, C. H. (1982). Children, Gender, and Social Structure: An Analysis of the Contents of Letters to Santa Claus. Child Development, Apr Vol 53 (2), 429-436. 
Rook, D. W. (1985). The ritual dimension of consumer behavior. Journal of Consumer Research, 12 (3), 251-264.

Rose, G. M., Bush, V. D., \& Kahle, L. (1998). The influence of family communication patterns on parental reactions toward advertising: A cross-national examination. Journal of Advertising, 27 (4), 71-85.

Ruth, J. A. (2001). Promoting a brand's emotion benefits: The influence of emotion categorization processes on consumer evaluations. Journal of Consumer Psychology, 11 (2), 99-113.

Schudson, M. (1986). The giving of gifts. Psychology Today, Vol 20(12), 26-29.

Sharpe, J. (2003, 11 December). Giving tree shows young Christmas is for everyone. Daily Telegraph.

Sherry, J. F. (1983). Gift giving in anthropological perspective. Journal of Consumer Research, Vol. 10 (2) (September), 157-168.

Sherry, J. F., McGrath, M. A., \& Levy, S. J. (1993). The dark side of the gift. Journal of Business Research, Volume 28 (Issue 3 November), 225-244.

Sheth, J. N., Newman, B. I., \& Gross, B. L. (1991). Consumption Values and Market Choices: Theory and Applications. Cincinnati: South-Western Pub.

Spangenberg, E. R., Voss, K. E., \& Crowley, A. E. (1997). Measuring hedonic and utilitarian dimensions of attitude: A generally applicable scale. In M. Brucks \& D. MacInnis (Eds.), Advances in Consumer Research (Vol. 24, pp. 235-241). Provo UT: Association for Consumer Research.

Sproles, G. B. (1974). Fashion theory: a conceptual framework. In Advances in Consumer Research (Vol. Volume 1, pp. 463-472).

St. Peters, M., Fitch, M., Huston, A. C., Wright, J. C., \& Eakins, D. J. (1991). Television and families: What do young children watch with their parents? Child Development, 62 (6, Dec), 1409-1423.

Stell, R., \& Paden, N. (1999). Vicarious exploration and catalog shopping: a preliminary investigation. Journal of Consumer Marketing, 16 (4), 332 - 346.

Wagner, J., Ettenson, R., \& Verrier, S. (1990). The effect of doner-recipient involvement on consumer gift decisions. In M. Goldberg, G. Gorn \& R. Pollay (Eds.), Advances in Consumer Research (Vol. 17, pp. 683-689). Provo, UT: Association for Consumer Research.

Wilson, W. R., \& Peterson, R. A. (1989). Some limits on the potency of word-of-mouth information. In T. Srull (Ed.), Advances in Consumer Research (Vol. 16, pp. 2329). Provo UT: Association for Consumer Research.

Wolfinbarger, M. F. (1990). Motivations and symbolism in gift-giving behavior. In M. Goldberg, G. Gorn \& R. Pollay (Eds.), Advances in Consumer Research (Vol. 17, pp. 813-825). Provo, UT: Association for Consumer Research.

Young Media Australia. (2004). Toy Advertising. Retrieved 22 November, 2009, from http://www.youngmedia.org.au/pdf/fact_sheets/03_03_toys.pdf 
Zhang, S., \& Sood, S. (2002). "Deep" and "Surface" Cues: Brand extension evaluations by children and adults. Journal of Consumer Research, Vol 29 (1) (June), 129141.

Zimmerman, A., Pereira, J., \& Kim, Q. S. (2003, 19 November). Wal-Mart Fires the First Shot in Holiday-Toy Pricing War. The Wall Street Journal. 
Table 1 Factor Structure - Evaluations of Giving Brands as Gifts

\begin{tabular}{|c|c|c|c|}
\hline Item Statements & Mean & Std Dev & Loadings \\
\hline \multicolumn{4}{|l|}{ Utility } \\
\hline \multirow{2}{*}{$\begin{array}{l}\text { The giving of a popular brand name at Christmas means I } \\
\text { give a gift that is guaranteed to last. } \\
\text { I give a popular brand name if I want to give a good quality } \\
\text { gift. }\end{array}$} & 2.60 & 1.83 & .894 \\
\hline & 2.58 & 1.74 & .864 \\
\hline $\begin{array}{l}\text { To me, the giving of a popular brand name as a Christmas } \\
\text { gift means giving a gift that is seen to be good value. }\end{array}$ & 2.80 & 1.84 & .842 \\
\hline Variance Explained & \multicolumn{2}{|c|}{ Cronbach Alpha } & .83 \\
\hline \multicolumn{4}{|l|}{ Hedonic } \\
\hline $\begin{array}{l}\text { Giving a popular brand name as a Christmas gift is giving a } \\
\text { gift that is a joy to give. }\end{array}$ & 2.25 & 1.59 & .801 \\
\hline $\begin{array}{l}\text { To me, the giving of a popular brand name at Christmas } \\
\text { means giving a positive gift. }\end{array}$ & 2.25 & 1.56 & .763 \\
\hline $\begin{array}{l}\text { To me, the giving of a popular brand name at Christmas } \\
\text { means giving a gift that will be well received }\end{array}$ & 2.51 & 1.72 & .747 \\
\hline $\begin{array}{l}\text { It is a pleasure for me to give a popular brand name as a } \\
\text { Christmas gift. }\end{array}$ & 2.92 & 1.86 & .739 \\
\hline Giving a good Christmas gift means a PBN & 1.66 & 1.16 & .722 \\
\hline Variance Explained & \multicolumn{2}{|c|}{ Cronbach Alpha } & .80 \\
\hline \multicolumn{4}{|l|}{ Symbolic } \\
\hline PBN shows the sort of person I am & 1.79 & 1.23 & .809 \\
\hline $\begin{array}{l}\text { I give popular brand names for Christmas gifts as signs of } \\
\text { my success. }\end{array}$ & 1.53 & 1.10 & .741 \\
\hline PBN says something about me & 2.19 & 1.60 & .736 \\
\hline $\begin{array}{l}\text { I give popular brand names as Christmas gifts because I } \\
\text { need to give the best gift available. }\end{array}$ & 1.63 & 1.09 & .701 \\
\hline PBN has recognized status appeal & 2.20 & 1.67 & .695 \\
\hline $\begin{array}{l}\text { Giving popular brand names as Christmas gifts make me } \\
\text { look good to others. }\end{array}$ & 1.60 & 1.14 & .686 \\
\hline Variance Explained & \multicolumn{2}{|c|}{ Cronbach Alpha } & .81 \\
\hline
\end{tabular}


Table 2 Popular Brand Names Disagree - Agree Responses

\begin{tabular}{|c|c|c|c|}
\hline \multirow{2}{*}{$\begin{array}{l}\text { Statement Item } \\
\text { Utility }\end{array}$} & \multicolumn{3}{|c|}{ Response Spread } \\
\hline & Disagree & Undecided & Agree \\
\hline $\begin{array}{l}\text { The giving of a popular brand name at Christmas means I give a gift } \\
\text { that is guaranteed to last. }\end{array}$ & 71.7 & 4.9 & 23.4 \\
\hline $\begin{array}{l}\text { To me, the giving of a popular brand name as a Christmas gift means } \\
\text { giving a gift that is seen to be good value. }\end{array}$ & 71.5 & 5.1 & 23.4 \\
\hline I give a popular brand name if I want to give a good quality gift. & 66.9 & 5.8 & 27.3 \\
\hline \multicolumn{4}{|l|}{ Hedonic } \\
\hline Giving a good Christmas gift means a PBN & 91.1 & 2.7 & $6.2^{*}$ \\
\hline $\begin{array}{l}\text { To me, the giving of a popular brand name at Christmas means } \\
\text { giving a positive gift. }\end{array}$ & 79.3 & 6.0 & 14.7 \\
\hline $\begin{array}{l}\text { Giving a popular brand name as a Christmas gift is giving a gift that } \\
\text { is a joy to give. }\end{array}$ & 79.0 & 6.3 & 14.7 \\
\hline $\begin{array}{l}\text { To me, the giving of a popular brand name at Christmas means } \\
\text { giving a gift that will be well received }\end{array}$ & 72.4 & 4.2 & 23.4 \\
\hline $\begin{array}{l}\text { It is a pleasure for me to give a popular brand name as a Christmas } \\
\text { gift. }\end{array}$ & 61.2 & 10.8 & 28 \\
\hline \multicolumn{4}{|l|}{ Symbolic } \\
\hline $\begin{array}{l}\text { I give popular brand names as Christmas gifts just to be noticed by } \\
\text { others.** }\end{array}$ & 97.1 & 1.1 & $2.8^{*}$ \\
\hline $\begin{array}{l}\text { I give popular brand names for Christmas gifts as signs of my } \\
\text { success. }\end{array}$ & 93.3 & 2.9 & 3.8 \\
\hline $\begin{array}{l}\text { I give popular brand names as Christmas gifts because I need to give } \\
\text { the best gift available. }\end{array}$ & 92.9 & 2.7 & 4.4 \\
\hline I must give the hottest brand of the year as a Christmas present. ** & 92.2 & 2.7 & 5.1 \\
\hline $\begin{array}{l}\text { Giving popular brand names as Christmas gifts make me look good } \\
\text { to others. }\end{array}$ & 91.5 & 3.6 & 4.9 \\
\hline $\begin{array}{l}\text { I show the sort of person I am by giving a popular brand name as a } \\
\text { Christmas gift. }\end{array}$ & 88.2 & 5.6 & 6.2 \\
\hline $\begin{array}{l}\text { Giving of popular brand name as a Christmas gift says something } \\
\text { about me. }\end{array}$ & 79.1 & 6.9 & 14.0 \\
\hline $\begin{array}{l}\text { I am giving a gift that has recognized status appeal when I give a } \\
\text { popular brand name as a Christmas gift. }\end{array}$ & 77.9 & 4.9 & 17.2 \\
\hline
\end{tabular}


Table $3 \quad$ Use Level of Information Sources

\begin{tabular}{|l|ccc|}
\hline Information Source & \multicolumn{3}{|c|}{ Use Level } \\
& Low & Medium & High \\
\hline My Children & 20.4 & 20.9 & 58.7 \\
Catalogues & 25.5 & 20.6 & 53.9 \\
Toy Departments & 39.1 & 25.4 & 35.5 \\
Specialist Toy Stores & 45.9 & 25.6 & 28.4 \\
Other People & 37.7 & 32.5 & 29.7 \\
Other Children & 49.7 & 22.6 & 27.6 \\
Press Advertisements & 55.0 & 22.1 & 22.9 \\
Had one as a child myself & 60.8 & 22.7 & 16.5 \\
Television Advertisements & 62.7 & 21.0 & 16.3 \\
Television Shows & 81.8 & 10.4 & 7.9 \\
Internet & 84.6 & 8.1 & 7.4 \\
Movies & 94.1 & 5.0 & 0.9 \\
\hline
\end{tabular}

